衛星通信・移動体通信技術の医療応用

一バイオテレメトリ手法による救急医療支援一

Medical Applications of Satellite and Mobile Communication

- Support for emergency medicine with biotelemetry technique-

清 水 孝一

北海道大学 工学部 システム情報工学専攻

Koichi Shimizu

Faculty of Engineering, Hokkaido University

1.はじめに

バイオテレメトリ手法とは，“通信手段を利用した生体情 報の遠隔計測手法”であり，工学技術を医療に応用した成功 例の一つである。近年の通信技術の進歩に伴い, 臨床医学, スポーツ医学, 宇宙医学などの分野で, テレメトリの応用 およびテレメトリ新技術の開発が盛んである ${ }^{1,2)}$.

我々はこれまで，バイオテレメトリ手法を用い，衛星通 信・移動体通信技術による救急医療の高度化をめざし研究を 行ってきた ${ }^{3,4)}$ 。ここでは，それらの概要および可能性を 調べるため行った実験の結果について報告する。

\section{2. 方 法}

Fig. 1 に伝送システムの概略を示す．移動局は患者のい る移動体 (例えば救急車や救急ヘリコプター, 患者の発生し た船舶や航空機)，固定局は救急救命センターや救急病院な どに対応する.

移動局では, 音声, 生体情報(複数チャネルの心電図, 血 圧，血液酸素飽和度など)，および患者の様子を映すカラー 画像 (連続静止画)を多重化し, 地上回線または衛星回線の 送信器へと入力する。これらの情報を, 地上無線系あるい は通信衛星を介して固定局へと送る. 固定局では, 受信器 からの信号を分離復調し, 医師へと提示する。医師は, 得 られる音声, 生体情報, 画像をもとに患者の状態を判断す るとともに，引き続き監視を行う．患者の処置や搬送先に 関する医師からの指示は, 再び通信回線を通して固定局か ら移動局一伝えられる。

\section{3. 画像伝送実験}

走行中の救急車から，無線回線 (自動車無線および救急無 線)を介してカラー画像を伝送する実験を行った．標準的な データ伝送速度は $4800 \mathrm{bps}$ であり，数十秒に一画面の割合で 更新される連続静止画の伝送が可能であった. 種々の道路 環境および走行状態において実験を繰り返した結果，通常 の条件では実用上問題となる点は見出せなかった. トンネ ル状の構造物内や強力な電磁雑音源の近傍以外では, 画面 の一部にノイズが混入しても, 救急車内の様子の把握が困 難になることはほとんどなかった。

\section{4. 衛星回線を用いた伝送実験}

本手法の具体的な可能性を調べるため，試作システムを 用いて基礎的実験を行った。本システムの衛星通信路には 技術試験衛星 V 型 (ETS-V) の回線 (24kbps, MSK) を使用した。

固定局での衛星折り返し実験において本システムの基本 的な動作を確認した後, 航海中の船舶および飛行中の航空 機からの伝送実験を行った。船舶実験は日本沿岸を航行す る北海道大学水産学部練習船「おしょろ丸」から，航空機実 験は成田ーアンカレッジ間を往復するジェット機 (JALCARG 0, Boeing 747F)から，それぞれETS-Vを介して地球局 (郵政 省通信総合研究所鹿島支所)にデータを伝送した。

実験では，画像·音声・心電図・血圧值など医用情報をそれ ぞれ個別に伝送し, 復号後のデータに対する伝送路状態の 影響を見た。これらの伝送結果をもとに，実用上支障のな い伝送を行うのに必要な伝送路品質を求め，医用情報伝送 の際の閥値とした。また，上記 4 種類の信号を多重化して 伝送し，実時間での分離再生機能の確認も行った。

これらの実験の結果，どの場合にも大きな問題はなく， 良好な伝送が可能なことを確認することができた。

\section{4.おわりに}

以上，救急医療支援をめざした衛星通信・移動体通信技術 の医療応用について述べてきた。このような研究を通し， 車両・航空機・船舶などの移動体に対し救急医療を提供する ことが可能なことが実証されたと考える。

今後は, 法律的制約の中で本手法をより現実的なものと するための検討が必要と考えられる.

\section{参 考 文 献}

1）清水孝一, BME, vol. 2, pp. 127-130, 1988

2）清水孝一，臨床モニター， vol. 3, pp. 327-339，1992.

3) H. Murakami, et al., IEEE Trans. Biomed. Eng. , vol. 41, pp. 488-497, 1994.

4) K. Shimizu, et al., IEICE Trans. Comm., vol. E78-B, pp. 818-825, 1995.

\section{Mobile Station}

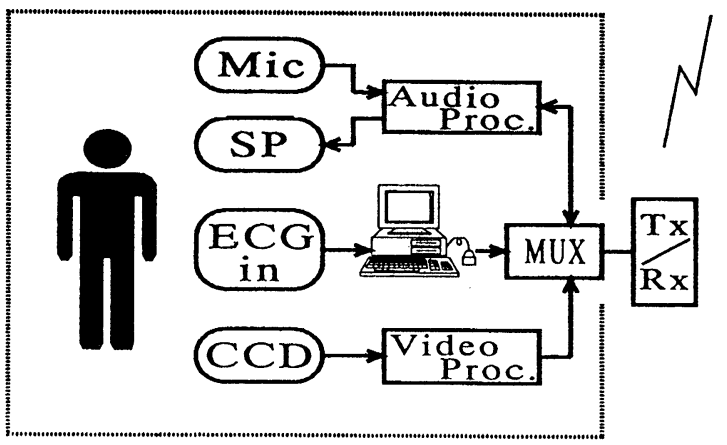

Fixed Station

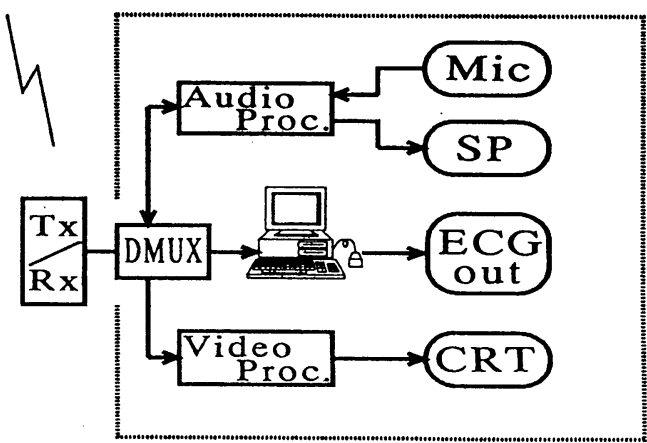

Fig. 1 Multiple data transmission system using mobile satellite communication. 


\title{
高柃者の精神的支援のためのマルチメディア利用
}

\section{On Application of Multimedia for the Mental Well-being of Elderly People}

\author{
○鈴木 真、小野智也、正宗賢、季林紅、土肥健純 \\ 東京大学大学院工学系研究科 \\ Makoto SUZUKI, Tomoya ONO, Ken MASAMUNE, Linhong JI, Takeyoshi DOHI \\ Graduate School of Engineering, the University of Tokyo
}

[はじめに]

我が国の社会の高齢化を背景とし、在宅高齢者の自立生 活に対して様々な面からの支援が望まれている. その中で 工学的支援である福祉機器は、高齢者の日常生活活動の自 立や介護者の負担軽減を目的として様々なものが市販され 利用されている.

これら福祉機器は主として加秡に伴う身体機能低下を補 うために利用されており、身体面での支援に重点を置いた ものである. しかし今後は在宅高齢者、特に独居高齢者が 增加すると予想されている. 彼等は孤独感や不安感などを 抱きがちであり、このような加粗や独居から来る精神的な マイナス面を解消する支援手段が必要となっている.

\section{[高撂者の精神的支援]}

精神面で高龄者が抱える問題として、特に独居の場合に は事故や発作などが起きた場合の対処について必要な助力 を直ちに得にくいという不安感がある. そこで現在、この ような緊急時のための通報システムが各所で運営され利用 されているが、実態は孤独感からの話し相手欲しさによる 呼び出しが多い. 従って他者とのコミュニケーションの機 会を十分に提供する必要があると考えられる. 特に身体面 での不自由から外出しにくく地域の交流活動にも参加でき ないような場合には、緊急時の対応だけでなく日常的に高 齢者宅を訪問し話し相手となることが必要となってくる.

このような高齢者の精神面での支援は人的なものによる のが最良であるが、限られた介護労働力では高齢者宅を訪 問し話し相手として十分な時間を割くことは困難である. そこで工学的な補助手段を用いることで人的支援を効果的 に運用し、総合的な支援の質を維持することが望まれる.

\section{[マルチメティアの利用]}

マルチメディア、特に音声と画像の同時双方向の通信 は、遠隔の家族や介護者と質の高いコミュニケーションを 提供し高龄者の精神的支援に貢献するものである.

現在の緊急通報システムでは電話を基礎としているもの が多い. しかし音声だけでは必要な情報が迅速に伝わりに くいことがあり、画像情報の利用が効果的である。 そこで キャプテンシステムや I S D Nを基礎としたテレビ電話に より高制者宅とサービスセンターを結び、緊急時の対応や 日常の相談に応じるシステムが各所で研究的に運用されて きている. 例えばヨーロッパではE C のCOST 219プロジェ クト（1986～1991）において、高齢者宅でのテレビ電話に よる相談システムのパイロットテストが行われた。 ここで は、話し相手欲しさによる利用が多かったこと、システム
自体の有用性が認められた一方で機器の導入には抵抗が あったこと等が報告されている．我が国における最近の事 例では、1996年夏に富山県山田村にて全世帯の 7 割にバソ コンを配り様々な試みを行っているが、その中で高齢者の 在宅ヶアにテレビ電話機能などを利用できるのではないか という考えが生まれつつある.

高齢者の精神的支援という観点からは、こうしたシステ ムの最大の利点はメディアの双方向性にある．在宅でも施 設でも、高齢者は興味関心の強弱にかかわらずテレビを見 ていることが多いが、一方的に情報を受け取るだけのメデ イアでは精神的健康の向上につながりにくいと考えられ

る. 双方向に通信可能なメディアでは、高齢者からの働き かけが可能となり、更にその働きかけに応じて適切な反応 が返ってくることで新たな働きかけが生まれ、結果として 高齢者が主体となったコミュニケーションが実現される.

我々はこのような高跉者主体のコミュニケーションによ る精神的支援において、介護者の補助を目的としバーチャ ルリアリティーを利用して仮想的な人物を提示し高齢者の 話の聞き役となるシステムについて研究している. 具体的 には高齢者の話の中のキーワードに応じて簡単な応答を返 すための会話データベース、会話以外の高齢者の活動状態 を判断するためのセンサシステム、高齢者が好む人物を合 成提示するためのディスプレイなどについて研究を行って いる.これらを人的な支援の補助としてマルチメディア技 術による高齢者へのサービスの中に組み入れることで、新 しい形の精神的支援が実現できると考える.

[おわりに]

以上に述べたようなマルチメディアによる高齢者の精神 的支援が普及するためには、まずハードウェア面において FTTH(Fiber To The Home)の推進による通信インフラストラ クチャの整備が重要である. また現状ではパソコン一・式の 価格は数十万円であり、廉価な端末の開発・普及が望ま㧈 る. ソフトウェア面では、運動や感觉機能が低下してもパ ソコンを使えるためのアクセシビリティの充実や、慣れな い高齢者にも分かりやすい操作インターフェースの実現が 課題である. そして何よりもパソコン嫌いの高齢者にも利 用してもらえるような、魅力あるアプリケーションの開発 が重要である. バーチャルリアリティー技術等の応用は、 取りつきやすく続けて使いたくなるような要素を盛り込む ことが可能となり、精神的支援のためのアプリケーション の実現に貢献すると考えられる. 


\title{
在宅医療・福祉とマルチメティア技術
}

\author{
A p p l i c a t i o n o f $\mathrm{Mul}$ t i m e d i a \\ $\mathrm{T}$ e chn i ques $\mathrm{t}$ o $\mathrm{Home} \mathrm{Car}$ e \\ ○稲田紘 \\ 国立循環器病センター研究所 \\ Hiroshi Inada \\ National Cardiovascular Center Research Institute
}

\section{1. はじめに}

高龄化の進展に伴い、老人医療費高騰の抑制や看護婦な ど医療マンパワーの不足への対処などのため、在宅医療・ 福祉（以下、単に在宅医療と称する）の必要性が増してい る。在宅医療の本格的な推進にあたり、ME（医用工学） 技術や情報・通信技術を応用してマンパワー不足に対処す るのみならず、在宅医療のレベル向上や在宅患者の生活の 質（QOL）の改善をもたらすことが研究されている。

情報・通信技術のうちでもマルチメディア技術は最近、 急速な発展を示し、医学・医療分野でも応用が開始されて いるが、在宅医療においても今後マルチメディアを含む情 報・通信技術の応用により、次のような事項が円滑に行わ れることが期待されている。すなわち、(1)病態把握などの ための患者情報の収集・記録、(2)患者情報の時系列的蓄積 之必要時における検索、(3)患者の治療・処置・介護などに 要する情報の医療・福祉従事者への提供、(4)医療・福祉関 係者間での連絡や情報交換、(5)患者への教育情報の提供、 といったことなどである。これらの在宅医療関連情報は、 動画像を含む画像や音声など多様なものについて、種々の 手段・方法で処理されることが要請される。

在宅医療・福祉におけるマルチメディア技術の応用はま だ入口にさしかかったところではあるが、本稿では著者ら の研究を含め、現在進められているパイオニア的な研究と 今後の方向性について述べる。

\section{2. 在宅医福祉におけるマルチメティアの具体的応用}

マルチメディアの在宅医療への応用は緒についてばかり であるが、広義のマルチメディア技術を含め、幾つかの具 体的試みが見られる。以下では今後の可能性を含めて、そ れらの代表的なものについて略述する。

2. 1 C A T VやTV電話による遠隔医療

遠隔医療では、映像機器による患者の状況に関する映像 伝送が重要になるが、在宅医療も一種の遠隔医療であり、 C A T Vや T V 電話を利用した幾つかの試用がすでに行わ れている。これにより、(1)在宅患者之医療施設の医師との 対面、(2)訪問看護婦やヘルパによる患者とその家庭環境な どに関するリアルタイムでの視覚的報告、(3)心電図や各種 検查結果の表示など視覚的患者情報の医療施設への伝送、 (4)医師よる遠隔診断之患者あるいは看護婦・ヘルパなどに 対する指示、といったことが可能となる。現在、まだアナ ログ TV電話が主流であるが、将来、光ファイバが各家庭 にまで數設されれば、その有用性が増すと期待される。
2. 2 画像情報を含む在宅患者情報収集システム

在宅医療では、病態把握や患者管理のための種々の患者 情報の収集・記録が重要で、このため各種の在宅患者情報 収集・記録システムの開発研究が少なからず進められてい る。これに関するものとして、著者らはディジタルカメラ と I S D Nによる電話機を用い、患者の各種バイタルサイ ンおよび症状・愁訴・容態のような定性的情報とともに、 顔貌や皮䖉の色、あるいは皮痛変などをパソコンを介し て患者宅から医療施設へ伝送するシステムを開発中である。 2. 3 光カードシステムの在宅医療への応用

最近、I Cカードや光カードの医療応用の試みが盛んて あるが、在宅医療への応用も始められている。神奈川県伊 勢原市では、65歳以上の住民に光カードを配布し、これに 住民の基本情報、救急情報、健診情報、福祉サービス記録、 保健指導記録などを記録して、診療所を中心とする住民の 医療や健康管理を主体にこのカードを用いている。その一 環として、保健婦にノートパソコンを携帯させ、在宅医療 受診者、在宅䕕たきり老人などに対する訪問指導、訪問看 護、在宅りハビリといったことにも利用している。研究段 階ながら、著者らは、循環器外科手術を受けた在宅患者の 管理にI Cカードを用いるシステムの開発を始めている。 2. 4 在宅医療・福祉のための教育・広報システム

住民に対する医学教育や健康教育は疾病の 1 次予防のた めに重要であるが、こうした教育は在宅患者に対しても、 疾病の 2 次予防や 3 次予防の観点から重要である。そこで 著者らは、アメリカにおいてマルチメディアを用いた住民 健康教育がなされているのにならい、マルチメディアによ る広報を含めた在宅医療教育システムを開発中である。現 在のところ電子教科書のように C D - R O Mが基本である が、インターネットを含めたネットワーク型のものや、多 人数を対象としたシア夕型のものをも計画している。

\section{3. マルチメティアを応用した将来の在宅医㙩・福祉支嗳 情報システム}

マルチメディアなどの情報技術の導入による在宅医療支 援情報システム構築の有用性についてはいうまでもないが、 このシステムの将来の方向性として、次のようなものが有 用と考えられる。すなわち将来のシステムは、マルチメデ ィアの応用がなされてもそれが単独で稼街するようなもの では不十分であり、当該地域の保健・医療・福祉関連の種 々の施設や関係者を結んだネットワークシステムのサブシ ステムとしての機能を発揮するものであることが望まれる。 
$1-s-4$

光ファイバーを用いた遠隔診断の実践

Telemedicine using ISDN 1500

○吉田暴管、廣川博之、秋葉 純*門 正則

小笠原博宣、石子智㐊、入江宏之*、今村達彌*

旭川医科大学眼科学教室

* 松下電器産業株式会社研究本部

**松下通信工業株式会社営業推進本部

Akitoshi Yoshida, Hiroyuki Hirokawa, Jun Akiba, Masanori Kado, Hironobu Ogasawara, Satoshi Ishiko, Dept. of Ophthalmology, Asahikawa Medical University. * Hiroyuki Irie, Corporate Research Division, Matsushita Electric Industrial C0, LTD. **Tatsuya Imamura, Corporate Marketing Promotion Division, Matsushita Communication Industrial C0, LTD.

我々は、1994年からカラー動画像を用いて眼科領域にお ける遠隔診断、遠隔治療支援を行ってきた。当初は、北海 道内における医師の偏在化、地域特異性を代償する過疎地 医療に対する対策として、このシステムを構筑した。しか しながら、近年のテクノロジーの進歩は著しく、このシス テムは医療現場における数々の問題点を解決すべく、学・ 産・官の三位一体の強い協力体制のもとで、医療の形態そ のものを変える、新しいシステムとして、今日、日々進歩 している。もはや、道内のみならず、全国、全世界へと広 まろうとしている。

本講演では、1996年12月12日現在の我々のシステムを、 スライドとビデオを用いて供覧したい。 